\title{
Students bullying teachers: Understanding and behavior of college students from a higher education institution
}

\author{
John Mark R. Asio \\ La Consolacion University Philippines, Gordon College, Philippines
}

\begin{abstract}
Student bullying a teacher is a phenomenon given with the least attention and focus since the perpetrators were seen as the academe itself. This descriptive study aims to determine the understanding and behavior of students in a higher education institution towards teacher bullying. The study surveyed 105 conveniently selected respondents from the three (3) different departments of a local community college in Olongapo City who were currently enrolled within the school year of 2017-2018. A draft questionnaire was created and submitted for validity, reliability, and consistency checks from different experts. The data collected were then processed using SPSS 22. The following results were generated: the respondent was a female, 18-20 years of age, first-year level and studying under the College of Business and Accountancy. The respondents moderately understood the idea of teacher bullying by students and their behavior towards teacher bullying by students is slightly inappropriate. Significant findings were found when the variables were grouped according to the year level and the department. There was also a low direct relationship that was observed between the understanding, year level and department. Based on the results, pertinent institutional policies and programs were recommended and suggested.
\end{abstract}

Keywords: Behavior; Local community college; Students; Teacher bullying; Understanding

Article History: Submitted 21 December 2018; Revised 2 April 2019; Published online 23 May 2019

\section{Introduction}

The concept of the teacher being bullied in higher education is a collective occurrence yet disregarded to some extent because of its nature and its interpretation in the public eyes. As stated by Mitchell (2016), there were a few studies in the past that dwell on bullying of students with their teachers. However, Kauppi and Porhola (2012) showed that previous studies suggest students bully many teachers worldwide. As told by Benton, Stroschen, Cavazos, and McGill (2014), bullying in higher education is a common phenomenon and it affects organizational climate, completed work's quality and quantity, and students' educational experiences. Koiv in 2014 compared the prevalence of teacher multi-targeted workplace bullying and found a substantial increase during the past ten years. On the accounts of Berliner (2011), a massive 90\% of

Address of Corresponding Author

John Mark R. Asio, Gordon College, Valenzuela St., Capitol View Park Subdivision,, Malolos, 3000 Bulacan, Philippines.

$\triangle \backslash$ asio.johnmark@gmail.com

0000-0002-6096-4595

How to cite: Asio, J. M. R. (2019). Students bullying teachers: Understanding and behavior of college students from a higher education institution. Journal of Pedagogical Research, 3(2), 11-20. 
the teachers surveyed in the Internet complained of teacher bullying. Kopecky and Szotkowski (2017) showed a fifth of the teacher-respondents have experienced cyberbullying in their study.

It has a significant impact on a variety of factors, and it contributes a considerable effect on the individuals involved. According to Longobardi, Badenes-Ribera, Fabris, Martinez, and McMahon, (2018) the prevalence of violence perpetrated against teachers by students showed a range of $20 \%$ to $75 \%$ with a pooled prevalence of $53 \%$ within $<2$ years' time frame. To supplement, Ozkilic and Kartal (2012) reported that teachers' stress level has increased, there was a bad atmosphere in the classroom and their expectation for students and the profession has decreased. Qiao (2018) showed that they do not respect American and Chinese teachers in their current teaching environment. Hollis (2015) also reiterated that when leadership allowed bullying to flourish, employees disengaged from the work tasks, spending hours regrouping from hostile interaction. Thus, May and Tenzek (2018) implored bullying is problematic on multiple levels in the academe. Caldwell (2017) also exposed the lack of resources to address victimized teachers and revealed that there were very few evidenced-based programs that may assist teachers and school administrators to combat bullying. Kauppi and Porhola (2012) reported teachers' exposure to different bullying by students, and the male students were doing the bullying.

There are different factors that played along with the bullying on teachers in different settings. A study of Pyhalto, Pietarinen, and Soini, (2015) confirmed such a notion, and they showed that the teacher-working environment plays a role. The said variables can function as inhibitors of both teacher-targeted bullying and exhaustion. In addition, there are significant effects that bullying can generate to a certain individual like what Moon and McCluskey (2014) speculated in their research where victimized teachers can suffer psychological distress, impaired personal relationships, and report higher levels of fear, leading to detrimental impacts on their job performance and relationships with students. From the perspectives of Fox and Stallworth, (2010) pervasive bullying and violent acts associated with strains in zero-order correlations, but when regressed, pervasive bullying rather than violence associates with strains. They further conferred that relations between violent acts and strains moderated satisfaction with the administrations' handling of violent acts. The team of Merilainen, Sinkkonen, Puhakka, and Kayhko, (2016) did a factor analysis and revealed three dimensions of bullying: exclusion and discrimination, personrelated belittlement and professional undermining. These dimensions were consistent with the categories of the consequences of bullying or inappropriate behavior based on open-ended answers. The findings also specified that teachers know of isolated and ongoing student bullying by their colleagues. However, they have a higher sense of accountability for peer bullying and forms of bullying with physical instead of socio-emotional concerns. (Zerillo \& Osterman, 2011). Subsequently, Orange (2018) divulged that the main reasons teachers feel bullied were their age, their association with a union and their behavior. Misawa (2015) revealed three types of bullying: (a) positional bullying, (b) counter-positional bullying, and (c) unintentional conspirative positional bullying which enable them to bully a person in a position of power between them, with that person's race, gender, or sexual orientation.

There is a dearth in the local studies and literature in the country pertaining to this research, but one study of Tolentino (2016) pointed out that there were four major types of bullying experienced by teachers: emotional, verbal, physical, and cyberbullying. She also added that workplace bullying negatively affects all facets of the teachers' lives like their physical health, psychological health, and social health. In the opinion of Llego (2016), students can bully a teacher by displaying terrible behavior in the class just to get attention and eventually distract them from focusing on the lesson and on the teacher. He added that even outside the classroom, the use of social media can bully teachers or can do this even sending insulting texts and instant messages to other students via cellular phones or computers.

According to the news report of Dela Cruz (2013), the chairman of Teacher's Dignity Coalition (TDC), Benjo Basas, stated that cases of students bullying teachers have been increasing in the country. The worst so far was the case of a teacher stabbed and killed by a student. 
This study aimed to produce baseline figures and facts regarding the understanding and behaviors of students towards students bullying teachers at the college level. The paper hopes to provide essential information about teacher bullying and its significance to the teaching profession. Also, the researcher expects a more drastic move and orientation to policy-makers to give this idea a little attention to the simple notion that teachers are very essential in molding the future generation. Last, to add up to the research world some substantial data that would be very beneficial for future researchers who will endeavor in the same field.

\section{Method}

\subsection{Research Design}

The study made use of a descriptive research design with the use of a survey as a primary instrument. As stated by Salaria, (2012), survey research uses scientific method by analyzing and examining the source materials, by analyzing and interpreting data and by arriving at generalization and prediction. Since the researcher is trying to describe certain characteristics of a population or phenomenon, it used the descriptive method.

\subsection{Participants}

A total of 105 college students have been included in the study using a convenience sampling technique (see Table 1). The participant is a bona fide student, enrolled and studying within the semester of Academic Year 2017-2018 in a Higher Education Institution in Olongapo City.

Table 1.

Descriptive Data of the Respondents

\begin{tabular}{|c|c|c|}
\hline Sex & Frequency & Percentage \\
\hline Male & 30 & 29 \\
\hline Female & 75 & 71 \\
\hline Total & 105 & 100 \\
\hline \multicolumn{3}{|l|}{ Age Bracket } \\
\hline $18-20$ years old & 84 & 80 \\
\hline $21-25$ years old & 10 & 9 \\
\hline $26-30$ years old & 4 & 4 \\
\hline 31 years old above & 7 & 7 \\
\hline Total & 105 & 100 \\
\hline \multicolumn{3}{|l|}{ Year Level } \\
\hline $1^{\text {st }}$ year & 47 & 45 \\
\hline $2^{\text {nd }}$ year & 31 & 29 \\
\hline $3^{\text {rd }}$ year & 27 & 26 \\
\hline Total & 105 & 100 \\
\hline \multicolumn{3}{|l|}{ Department } \\
\hline College of Education, Arts \& Sciences & 26 & 25 \\
\hline College of Business and Accountancy & 57 & 54 \\
\hline College of Allied Health Studies & 22 & 21 \\
\hline Total & 105 & 100 \\
\hline
\end{tabular}

As shown in Table 1, the frequency distribution and percentage equivalence of respondents according to sex, age, year level, and department. We can deduce that most of the respondents were female and fall in the age bracket between 18-20 years old. It is also important to note that most of the respondents were at their first-year level and affiliated with the College of Business and Accountancy department. 


\subsection{Data Collection Tool}

The researcher created a self-made questionnaire after an exhaustive reading of related literature and materials. I then submitted it for critiquing to experts and professors who are practitioners in research for validity and reliability. I considered their comments in revising and completing the questionnaire. To furthermore test the clarity and validity of the questionnaire, it was first pilot-tested to senior high students who are not subject participants in the study for ambiguous or hard to understand words and terms.

\subsection{Data Analysis}

In this study, Pearson r, Analysis of Variance, t-test, the frequency count and weighted mean were used for the statistical analysis. All the data and information gathered are processed using SPSS 22. The weighted values assigned to the understanding and behavior of respondents was patterned after Likert scaling.

\section{Results}

Table 2 exhibits the mean distribution of respondent's understanding of students bullying teachers. We can observe it in statement 4 , got the highest mean. However, statement 15 got the lowest mean average. Both statements fall under the same descriptive interpretation of Understood. The overall mean is interpreted as Understood by the respondents based on the Likert scale.

Table 2.

Mean Distribution of Respondents on the Understanding of Students Bullying Teacher

\begin{tabular}{|c|c|c|c|}
\hline & Statement & Mean & $\begin{array}{l}\text { Descriptive } \\
\text { Rating }\end{array}$ \\
\hline 1) & $\begin{array}{l}\text { "Workplace bullying" refers to unreasonable behavior by an individual } \\
\text { that intimidates or degrades another individual in work. }\end{array}$ & 2.91 & Understood \\
\hline 2) & $\begin{array}{l}\text { Bullying negatively affects the physical or psychological health of the } \\
\text { targeted teacher(s). }\end{array}$ & 3.23 & Understood \\
\hline 3) & $\begin{array}{l}\text { Bullying generally involves repeated, unreasonable actions, but it can } \\
\text { also be a single, severe action. }\end{array}$ & 2.97 & Understood \\
\hline 4) & $\begin{array}{l}\text { Bullying can be in the form of shouting, threats of violence, malicious } \\
\text { gossips, etc.* }\end{array}$ & 3.42 & Understood \\
\hline 5) & $\begin{array}{l}\text { Anyone can bully a teacher such as students, staff, school } \\
\text { administrators, department head, etc. }\end{array}$ & 3.08 & Understood \\
\hline 6) & Policy on teacher bullying should be implemented in every institution. & 3.34 & Understood \\
\hline 7) & $\begin{array}{l}\text { Bullied teachers can report their situation to a committee in the school } \\
\text { for proper evaluation and counseling. }\end{array}$ & 3.18 & Understood \\
\hline 8) & There exists a law / policy that protects teacher from bullying. & 2.92 & Understood \\
\hline 9) & $\begin{array}{l}\text { Bullying can lead to personality breakdown and sometimes loss of } \\
\text { professionalism of a teacher. }\end{array}$ & 3.31 & Understood \\
\hline 10) & Every teacher is a possible target of bullying. & 3.18 & Understood \\
\hline 11) & $\begin{array}{l}\text { Bullying can be through social media, physical, emotional or } \\
\text { psychological means. }\end{array}$ & 3.41 & Understood \\
\hline 12) & $\begin{array}{l}\text { Bullied individuals (e.g. teachers) can be bullied inside or outside the } \\
\text { classroom. }\end{array}$ & 3.32 & Understood \\
\hline 13) & $\begin{array}{l}\text { Bullied teachers can suffer depression, physical deterioration and } \\
\text { sometimes loss of life. }\end{array}$ & 3.35 & Understood \\
\hline 14) & Bullying a teacher can also lead to unemployment of that individual. & 3.08 & Understood \\
\hline 15) & $\begin{array}{l}\text { A bullied teacher can fight back to those bullies but in a more } \\
\text { unexpected way.* }\end{array}$ & 2.79 & Understood \\
\hline & Overall Mean & 3.16 & Understood \\
\hline
\end{tabular}


Table 3 shows the mean distribution of respondents' behavior towards students' bullying teachers. We can analyze it that statement 3, got the highest mean which has a descriptive interpretation of Slightly Appropriate. Statement 12 got the lowest mean which has a descriptive rating of Slightly Inappropriate on the Likert Scale. The overall mean is interpreted as slightly inappropriate by the respondents as per Likert scaling.

Table 3.

Mean Distribution of Respondent's Behavior towards Students Bullying Teacher

\begin{tabular}{|c|c|c|c|}
\hline & Statement & Mean & Descriptive Rating \\
\hline 1) & $\begin{array}{l}\text { When I see acts of bullying or harassment to a teacher, I } \\
\text { report it. }\end{array}$ & 2.40 & $\begin{array}{c}\text { Slightly } \\
\text { Inappropriate }\end{array}$ \\
\hline 2) & I avoid students who bully teachers for fear of my own safety. & 2.71 & Slightly Appropriate \\
\hline 3) & $\begin{array}{l}\text { I disregard bullying behaviors of staff members towards } \\
\text { teachers.* }\end{array}$ & 2.88 & Slightly Appropriate \\
\hline 4) & $\begin{array}{l}\text { I make excuses or cover-up or defend certain students } \\
\text { involved in teacher bullying. }\end{array}$ & 1.84 & $\begin{array}{l}\text { Slightly } \\
\text { Inappropriate }\end{array}$ \\
\hline 5) & $\begin{array}{l}\text { I fear I will be reprimanded by school administration for } \\
\text { reporting teacher bullying. }\end{array}$ & 2.22 & $\begin{array}{l}\text { Slightly } \\
\text { Inappropriate }\end{array}$ \\
\hline 6) & $\begin{array}{l}\text { I believe the best way for targeted teachers to prevent future } \\
\text { incidents is to fight back. }\end{array}$ & 1.99 & $\begin{array}{l}\text { Slightly } \\
\text { Inappropriate }\end{array}$ \\
\hline 7) & I use violent language or actions while dealing with teachers. & 1.58 & $\begin{array}{l}\text { Slightly } \\
\text { Inappropriate }\end{array}$ \\
\hline 8) & I believe targeted teachers set themselves up to be bullied. & 2.07 & $\begin{array}{l}\text { Slightly } \\
\text { Inappropriate }\end{array}$ \\
\hline 9) & $\begin{array}{l}\text { I tend to overlook problem behaviors in teachers since it is not } \\
\text { my responsibility to check them. }\end{array}$ & 2.13 & $\begin{array}{l}\text { Slightly } \\
\text { Inappropriate }\end{array}$ \\
\hline & $\begin{array}{l}\text { I do not report teacher bullying incidents to protect the school } \\
\text { from social issues.* }\end{array}$ & 2.01 & $\begin{array}{l}\text { Slightly } \\
\text { Inappropriate }\end{array}$ \\
\hline & $\begin{array}{l}\text { If I get mad to a teacher, I send insulting text messages to my } \\
\text { text mates about that teacher. }\end{array}$ & 1.53 & $\begin{array}{l}\text { Slightly } \\
\text { Inappropriate }\end{array}$ \\
\hline & $\begin{array}{l}\text { I usually send "poison" letters to the school to degrade a } \\
\text { teacher that I do not like.* }\end{array}$ & 1.50 & $\begin{array}{l}\text { Slightly } \\
\text { Inappropriate }\end{array}$ \\
\hline & $\begin{array}{l}\text { I try to conspire with my fellow classmates to prank our } \\
\text { teacher whom we hate the most. }\end{array}$ & 1.56 & $\begin{array}{l}\text { Slightly } \\
\text { Inappropriate }\end{array}$ \\
\hline & $\begin{array}{l}\text { When I am angry with a teacher, I usually post my grievances } \\
\text { in the social media. }\end{array}$ & 1.55 & $\begin{array}{l}\text { Slightly } \\
\text { Inappropriate }\end{array}$ \\
\hline & $\begin{array}{l}\text { I use a "code" or "call sign" with my classmates to a specific } \\
\text { teachers }\end{array}$ & 1.92 & $\begin{array}{c}\text { Slightly } \\
\text { Inappropriate }\end{array}$ \\
\hline \multicolumn{2}{|r|}{ Overall Mean } & 1.99 & $\begin{array}{c}\text { Slightly } \\
\text { Inappropriate }\end{array}$ \\
\hline
\end{tabular}

Likert Scale: 1.00-1.49=Inappropriate; 1.50-2.49= Slightly Inappropriate; 2.50-3.49=Slightly Appropriate; 3.50-4.00= Appropriate

Table 4 represents the t-test on the understanding and behavior of students bullying teachers. It can be inferred that there are no significant differences in terms of understanding and behavior of the respondents towards students bullying teachers regardless of their sex since $t(103)=0.688$, $p>.05$ for the understanding of students bullying teachers and $t(103)=0.704, p>.05$ for behavior towards students bullying teachers. 
Table 4.

T-Test for Significant Difference in Understanding and Behavior on Students Bullying Teachers grouped according to Sex

\begin{tabular}{lccccc}
\hline & \multicolumn{2}{c}{ Male } & \multicolumn{2}{c}{ Female } & $t$ - test \\
\cline { 2 - 5 } & $\mathrm{M}$ & $\mathrm{SD}$ & $\mathrm{M}$ & $\mathrm{SD}$ & \\
\hline $\begin{array}{c}\text { Understanding of Students Bullying } \\
\text { Teachers }\end{array}$ & 3.15 & .545 & 3.19 & .522 & 0.688 \\
$\begin{array}{c}\text { Behavior towards Students Bullying } \\
\text { Teachers }\end{array}$ & 2.04 & .801 & 1.99 & .679 & 0.704 \\
\hline$d f=103 \quad$ & & & &
\end{tabular}

Table 5 shows the Analysis of Variance on the understanding and behavior of teacher bullying by students grouped according to age. It is safe to assume that there is no significant difference in the understanding and behavior of the respondents regardless of what age bracket they may belong to when it comes to students bullying teachers. The computed values were $F(3,101)=.133$ for understanding students bullying teachers and $F(3,101)=1.617$ for behavior towards teacher bullying, both have a $p>.05$.

Table 5.

ANOVA for Significant Difference in Understanding and Behavior on Students Bullying Teachers grouped according to Age

\begin{tabular}{cccccc}
\hline & & SS & dF & MS & $F$ value \\
\hline Understanding & Between Groups & 0.113 & 3 & 0.038 & 0.133 \\
& Within & 28.695 & 101 & 0.284 & \\
Tetal & 28.808 & 104 & & \\
& Totavior & 2.420 & 3 & 0.807 & 1.617 \\
& Between Groups & 50.383 & 101 & 0.499 & \\
& Within & 52.803 & 104 & & \\
& Total & & &
\end{tabular}

Table 6 displays the ANOVA on the understanding and behavior of students bullying teachers when respondents are grouped according to the year level. It can be scrutinized from the table that understanding on students bullying teachers yielded a significant value, since $F(2,102)=3.251, p<$ .05 , thus there exists a significant difference in understanding of the respondents based on the year level where they belong. However, behavior towards students bullying teachers did not get enough to provide significant results since $F(2,102)=2.462, p>.05$.

Table 6.

ANOVA for Significant Difference in Understanding and Behavior on Students Bullying Teacher grouped according to Year Level

\begin{tabular}{cccccc}
\hline & & $\mathrm{dS}$ & $\mathrm{dF}$ & $\mathrm{MS}$ & $F$ value \\
\hline Understanding & Between Groups & 1.726 & 2 & 0.863 & $3.251^{*}$ \\
& Within & 27.081 & 102 & 0.266 & \\
Total & 28.808 & 104 & & \\
& Behavior & 2.432 & 2 & 1.216 & 2.462 \\
& Between Groups & 50.371 & 102 & 0.494 & \\
& Within & 52.803 & 104 & & \\
& Total & & &
\end{tabular}

${ }^{*} p<.05$

Table 7 details the Analysis of Variance of the respondent on understanding and behavior on students bullying teachers grouped according to their department. Significant findings were found. The results include $F(2,102)=8.632, p<.05$ for understanding and $F(2,102)=6.459, p<.05$ 
for behavior. This stresses a significant difference in their response towards students bullying teachers depending on the department that they are affiliated.

Table 7.

ANOVA for Significant Difference in Understanding and Behavior on Students Bullying Teachers grouped according to Department

\begin{tabular}{cccccc}
\hline & & SS & dF & MS & $F$ value \\
\hline \multirow{3}{*}{ Understanding } & Between Groups & 4.170 & 2 & 2.085 & $8.632^{*}$ \\
& Within & 24.638 & 102 & 0.242 & \\
& Total & 28.808 & 104 & & \\
\multirow{2}{*}{ Behavior } & Between Groups & 5.936 & 2 & 2.968 & $6.459^{*}$ \\
& Within & 46.868 & 102 & 0.459 & \\
& Total & 52.803 & 104 & & \\
\hline
\end{tabular}

${ }^{*} p<.05$

Table 8 shows the relationship of understanding and behavior towards students bullying teachers with the profile of the respondents.

Table 8.

Correlation Matrix between Understanding and Behavior on Teacher Bullying by Students and Profile of Respondents

\begin{tabular}{lcc}
\hline & Understanding & Behavior \\
\hline Sex & .040 & -.037 \\
Age & -.045 & .146 \\
Year Level & $.245^{*}$ & -.051 \\
Department & $.352^{*}$ & -.138 \\
\hline
\end{tabular}

${ }^{*} p<0.05$

It can be deduced from Table 8 that only understanding portrayed a significant relationship with the year level and department of the respondents since $r=.245$ and .352 respectively. The rest of the variables did not yield significant results to qualify them with a relationship with others.

\section{Discussion}

The main purpose of this study is to assess the understanding and behavior of college students on students bullying teachers. This idea is prevalent for higher education institutions because of the advancement of technology, and the era of social media is just a touch away. Thus, teacher bullying has never been this "enthusiastic" than ever before. Little do we know that such practice has been emanating in the office, though this study only focused on students which bully teachers, its impact does not differ from the others. Based on the literature reviews of Prevost and Hunt (2018), the most common kind of bullying was psychological and emotional assaults. With this in mind, Ozkilic and Kartal (2012) mentioned that teachers frequently turned to guidance counselors, deputy headmasters, and headmasters for help in such situations. Although the perpetrator of bullying is unaware of such, it can be summed up to this by the victims who receive it. According to Meires (2018), evidence shows that incivility is a precursor of bullying in academia. Although factors can be related to bullying, it can lead to negative outcomes on the victims (Prevost \& Hunt, 2018). Considering the current situation that teachers in the different field are experiencing right now, there is little to no availability of a legitimate movement to exercise a fair and just execution of personal and professional rights of every teacher in the country.

In the study, we observed that the respondents have a moderate understanding of what teacher bullying by students is all about. The main concern here is the prevalence of bullying in the academe and do the perpetrators are guilty of it. Prevost and Hunt (2018) mentioned that bullying 
is often directed to other academics and faculty. Since they are the primary target, we cannot run away from the harsh reality of bullying, as teachers, we are in the frontline of the education system. In the words of de Wet (2010) lack of an effective regime for the monitoring of regulations on behavior and the characteristics of the bullies and victims are reasons for bullying which have the same idea as Reigel (2016), wherein she pointed the notion of the institutional process of reporting bullies in the workplace. Further, Koiv (2014) showed that for the past ten years, there was a substantial increase in the prevalence of teacher targeted bullying. Corroboratively, Kauppi, and Porhola (2012) said that based on the teachers' assessment, most of the students who bullied them also bullied their classmates. The contention of bullying has to do with different variables playing in the scene like personal insecurities, professional maladjustment, behavioral and attitudinal problems and many more. It is not simply a lop-sided agenda for everybody to consider.

It was also noted in the study that in teacher bullying, students were quite abashed with the idea of students bullying teachers thus, they projected a slightly inappropriate response to almost all the items. Unconsciously, the respondents could be guilty of committing such "crime" since he or she might be upset with that particular teacher and vented it out carelessly, like to social media or take it more aggressively on other matters. Corroboratively, Bradshaw, Sawyer \& O'Brennan (2007) reported that students and staff report the highest exposure to and concern about bullying. However, Reigel (2016) revealed that most instructors who were bullied were reluctant to report such an incident in the institution. This issue needs to be addressed along the line since. It may lead to various work-related and institutional consequences. (Prevost \& Hunt, 2018) Kauppi and Porhola (2012) identified three kinds of attribution for their victimization namely: student-related, institution-related and teacher-related. Being bullied has significant effect in the performance of an individual no doubt about it but understanding and promoting healing to the victims takes time which also means loss on the part of the organization.

Differences in the understanding and behavior of the respondents regarding the year level and the department made this study unique. There has been no literature that directly supports the results. The result of this study simply shows that there are some related factors that play in this unique environment in this local setting. However, Borochowitz and Desivillia (2016) claimed that faculty and students both have considerable similarities in identifying uncivil behavior and also, they both agree that the main cause lies in the penetration of norms from external culture. Kauppi and Porhola (2012) also offered that the selection of the persons with whom teachers shared their experiences was determined by the attribution. Moon and McCluskey (2016) suggested that teacher victimization is widespread and shows significant effects on the individual's sociodemographic factors, classroom atmosphere, and school-type.

Finally, concerning the relationship between the understanding and behavior of students towards teacher bullying and the profile variables, although there is a lack of related literature to support the results, Foley et al. (2014) provided some significant findings in their multivariate analysis that is partly related in the current study. Pyhalto, Pietarinen \& Soini (2015) showed that exhaustion and bullying were significant determinants of teacher turnover. Kopecky and Szotkowski (2017) emphasized that the longer the attack on the victim lasts, the more severe its impact. This only shows that there are so many ways how bullying can affect a teacher, depending on the process and the time which might take its toll in the end leading to impairment and significant life changes.

\section{Conclusion}

Based on data gathered, tabulated and analyzed, the researcher concluded that the respondent was a female, 18-20-year-old, first-year student, studying under the College of Business and Accountancy.

The respondents moderately understood the idea of students bullying teachers and they also behaved slightly inappropriate regarding the said issue. 
There was no significant difference in the results when understanding and the behavior of the respondents towards student bullying teachers were grouped according to sex and gender. However, regarding the year level and department, there was a significant finding. There was also a low direct significant relationship that was observed between the understanding of teacher bullying, year level, and department.

\subsection{Recommendations}

In view of the foregoing conclusions, the following recommendations are proposed by the researcher:

$>$ The School administrator should provide policies that focus on the protection of teachers in bullying.

$>$ Relative student education appertaining to the dos and don'ts between teacher-student relationships, both inside and outside the school campus.

$>$ Personality development seminar/ workshop for teachers to improve their image in front of their students and minimize teacher bullying.

$>$ Personnel education in bullying in the workplace, how is it done, and how should it be avoided or prevented.

$>$ Counseling for the bullied individual and provision of support group during the time of the rehabilitation program.

$>$ Lobbying of a law that gives protection and safeguards for bullied teachers with corresponding sanctions and punishments to those who are proven guilty

$>$ Conduct further researches and studies on this field.

\section{References}

Allen, K. P. (2010). Classroom management, bullying and teacher practices. The Professional Educator, 34(1), 1-15.

Bradshaw, C. P., Sawyer, A.L., \& O'Brennan L. M. (2007). Bullying and peer victimization at school: Perceptual differences between students and school staff. School Psychology Review, 36(3), 361-382.

Berliner, W. (2011). Guardian survey finds teachers want to be treated as professionals. The Guardian. Retrieved from www.theguradian.com/education/2011/Oct/13/teacher -surveyprofessionals-bullying-parents

Caldwell, M. (2017). The lived experience of female high school teachers who perceive they were targets of student bullying. Published doctoral dissertation. Capella University, Minnesota, USA.

de Wet, C. (2010). The reasons for and the impact of principal-on-teacher bullying on the victims' private and professional lives. Teacher and Teacher Education, 26(7), 1450-1459.

Dela Cruz, K. (2013). Who will protect the teachers from student bullies? ABS-CBNnews.com. Retrieved from www.newsabs-cbn.com/focus/10/11/13/who-will-protect-teachers-student-bullies

Garrett, L. (2014). The student bullying of teachers: An exploration of the nature of the phenomenon and the ways in which it is experienced by teachers. Aigne, 5, 19-40.

Hollis, L. P. (2015). Bully university? The cost of workplace bullying and employee disengagement in American higher education. Sage Open, 5(2), 1-11.

Kauppi, T., \& Porhola, M. (2012). School teachers bullied by their students: teachers' attributions and how they share their experiences. Teaching and Teacher Education, 28(7), 1059-1068.

Kauppi, T., \& Porhola, M. (2012). Teachers bullied by students: forms of bullying and perpetrator characteristics. Violence and Victims, 27(3), 396-413.

Koiv, K. (2014). Changes over a ten-year interval in the prevalence of teacher targeted bullying. ProcediaSocial and Behavioral Sciences, 171, 126-133.

Kopecky, K., \& Szotkowski, R. (2017). Cyberbullying, cyber aggression and their impact in the victim- the teacher. Telematics and Informatics, 34 (2). 506-517.

LLego, M. (2016). Students and parents bullying a teacher: A fast-spreading disease. TeacherPH. Retrieved from www.teacherph.com/students-parents-bullying-teacher-fast-spreding-disease/ 
Longobardi, C., Badenes-Ribera, L., Fabris, M. A., Martinez, A., \& McMahon, S. D. (2018). Prevalence of student violence against teachers: A meta-analysis. Psychology of Violence. Retrieved from http:/ / dx.doi.org/10.1037/vio0000202

May, A., \& Tenzek, K. E. (2017). Bullying in the academy: understanding the student bully and the targeted 'stupid, fat, mother fucker' professor. Teaching in Higher Education, 23(3), 275-290.

Meires, J. (2018). Workplace incivility: When students bully faculty. Urologic Nursing, 38(5), 251-255.

Misawa, M. (2015). Cuts and bruises caused by arrows, sticks, and stones in academia: Theorizing three types of racist and homophobic bullying in adult and higher education. Adult Learning, 26 (1), 6-13.

Mitchell, L. H. (2016). The role of prevention in deterring teachers bullied by students. Journal of Education and Learning, 5 (4), 300-305.

Moon, B., \& McCluskey, J. (2016). School-based victimization of teachers in Korea: focusing on individual and school characteristics. Journal of Interpersonal Violence, 31 (7), 1340-1361.

Ozkilic R., \& Kartal, H. (2012). Teachers bulled by their students: how their classes influenced after being bullied? Procedia-Social and Behavioral Sciences, 46, 3435-3439.

Pepler D., (2011). Prevent bullying by promoting healthy relationship. Research for Teachers, 6, 1-3.

Prevost C., \& Hunt, E. (2018). Bullying and mobbing in academe: A literature review. European Scientific Journal, 14 (8), 1-15.

Qiao, B. (2018). Educator-targeted bullying: cross-cultural perspective (Unpublished master's thesis). University of Kansas, USA.

Reigle, R., (2016). Bullying of adjunct faculty at community colleges and steps towards resolution. Retrieved from https://eric.ed.gov/?id=ED563989

Salaria, N. (2012). Meaning of the term - descriptive survey research method. International Journal of Transformations in Business Management, 1(6), 1-7.

Samnani, A.K., Singh, P., \& Ezzedeen S. (2013).Workplace bullying and employee performance: An attributional model. Organizational Psychology Review, 3(4), 337-359.

Tolentino, A. C. (2016). Bullying of a teacher in the workplace: A phenomenological study. International Journal of Learning and Teaching, 2(1), 20-27. 